Tatiana Maciejewska

Uniwersytet Zielonogórski

\title{
Siłownia jako miejsce konstruowania męskiej tożsamości cielesnej
}

W społeczeństwach nowoczesnych, zachodnich, szybko rozwijających się, w których następuje kryzys kultury, rewolucja obyczajowa, obraz męskości i kobiecości ulega przedefiniowaniu. W człowieku zagubionym $\mathrm{w}$ obrazie płci pojawia się potrzeba świadomego jej kreowania na różne sposoby. Sfera cielesna, wizualna stała się tablicą, na której tworzyć można własny wizerunek. Podążać za modą lub się jej sprzeciwiać. Podkreślać lub unifikować płciowość. Nancy Etcoff (2002, s. 13) uznaje wygląd za publiczną część jaźni, widzialne "ja”. Jej zdaniem atrakcjonizm jest najbardziej powszechnym, a zarazem skrywanym uprzedzeniem funkcjonującym w społeczeństwach w sposób nieświadomy. Wygląd traktowany jest jako źródło przyjemności, wstydu, informacji. Zdaniem badaczki przyczyną treningów w siłowni, poprawiania natury w gabinetach chirurgicznych jest chęć bycia nie tylko dziełami natury, ale i dziełami sztuki. Fitness klub stał się z jednej strony przestrzenią do tworzenia siebie, budowania swego cielesnego "ja”, z drugiej - miejscem reżimu cielesnego. Swoistym panoptikonem, w którym jednostka sama dla siebie jest strażnikiem, krytykiem i więźniem jednocześnie. W kulturze ponowoczesnej istnieje możliwość społecznego „negocjowania" własnej roli, tożsamości, postaw oraz obrazu ciała. Dopuszczalny jest „margines błędu", odstępstwo od wypełniania tradycyjnych ról. Decydowanie o kreacji siebie stało się akceptowane, a nawet wymagane. Swobodne żonglowanie tożsamościami pozwala budować siebie niczym z klocków. Zachowanie elementów tradycyjnych nie wyklucza wprowadzenia nowinek kulturowych. Jednostka coraz częściej tworzy siebie w sposób ostentacyjny. Kreuje autoekspozycję na scenie społecznej.

W artykule przedstawiony został fragment badań dotyczących postrzegania i kreowania męskiej tożsamości przez mężczyzn ćwiczących w siłowniach. Jest to próba stworzenia obrazu mężczyzny kreującego swoją tożsamość wizualną, cielesną, ostentacyjną. Przytoczone zostały wypowiedzi badanych dotyczące wybranych kwestii. Podjęta problematyka wymagała analizy nie tylko zachowań, ale przede wszystkim odczuć związanych z byciem mężczyzną we współczesnym 
świecie. Badani znajdują w siłowni narzędzia do konstruowania swojej podmiotowości. Jest ona dla nich miejscem budowania i niszczenia. Budowany jest cielesny pancerz, niszczona słabość i kruchość. Symbolika muskulatury daje im poczucie stabilizacji, zatopienia w tradycyjnym wymiarze męskości. Zdaniem Raewyn Connella (1995, s. 54) męskość jest modelem płci kulturowej, zespołem praktyk inicjowanych przez ciało, zorientowanych na ciało i odnoszących się do ciała. Ciało jako obiekt praktyk społeczno-kulturowych staje się uczestnikiem owych procesów. Connell (1995, s. 86) wyróżnia elementy reżimu płciowego - relacje władzy, stosunki produkcji, struktury emocjonalne, symbolizację. Jest zwolenniczką pojmowania męskości jako projektu płciowego, będącego odpowiedzią na istnienie wielu jej modeli. Pierre Bourdieu (2001, s. 52) uważa, że mechanizm konstruowania płci bazuje na odpowiednim zaaranżowaniu ciała w systemie praktyk społecznych, inkorporacji relacji panowania. To kulturowe dystynkcje kierują wyborem kształtu własnej cielesności. Odróżnianie się polega na podejmowaniu zachowań cielesnych oraz tworzeniu określonego wizerunku własnego ciała. W świecie jest się w sposób cielesny. Fundamentalne dyspozycje narzucają społeczne strojenie ciała, które poddaje się permanentnej reprodukcji. Ciało w tym rozumieniu jest wizytówką - staje się wyrazem miejsca zajmowanego w porządku społecznym i płciowym. Ciało płciowe jest ciałem społecznym i politycznym, a męskość konceptem dynamicznym.

\section{Charakterystyka badanych mężczyzn}

Badaniami objętych zostało dwunastu mężczyzn w wieku między 20 a 55 rokiem życia. Systematycznie ćwiczących w siłowni, prezentujących sportowo-atletyczny typ sylwetki. W badaniach zastosowana została strategia jakościowa. Prowadzone były one przy użyciu metody studium przypadków. Dobór próby zorientowany był na uzyskanie informacji - dobór przypadków na podstawie oczekiwań zawartości informacji umożliwia maksymalizację użyteczności informacji z małych prób i pojedynczych przypadków (Flyvbjerg 2005, s. 53). Badaniami objęci zostali mężczyźni o określonej budowie ciała, wskazującej na regularne treningi siłowe. Kryteriami doboru próby były: okres ćwiczeń (minimum 2 lata systematycznych treningów w siłowni), budowa ciała (wskazująca na trenowanie w siłowni). Sześciu badanych posiada wykształcenie wyższe, pięciu średnie, a jeden jest studentem. Czterech badanych określa swój zawód jako przedsiębiorca. Działają w branżach: rozrywkowej, handlowej, elektronicznej, ubezpieczeniowej. Trzech jest instruktorami kulturystyki (dwóch z nich pracuje w siłowniach). Jeden badany jest sprzedawcą w sklepie specjalistycznym, a kolejny pracuje w branży finansowej. Inny jest prawnikiem, następny właścicielem warsztatu mechanicznego. Połowa badanych to mieszkańcy Zielonej Góry, a druga połowa Warszawy. W badaniach przyjęta została strategia jakościowa. Końcowy materiał badawczy uzyskany został w trakcie dwunastu wywiadów narracyjnych oraz w czasie prowadzenia obserwacji. Ograniczenie liczby badanych pozwoliło zredukować wy- 
stępowanie problemów związanych z nazbyt obszernym materiałem, co z kolei uniemożliwiłoby dotarcie do głębi sensu wywiadów przy dokonywaniu analizy. Analiza jest zabiegiem wymagającym wiele czasu, a przy zbyt dużej ilości zebranego materiału badawczego rośnie możliwość powierzchownego jej przeprowadzenia. Z każdym badanym odbyło się spotkanie mające na celu przeprowadzenie wywiadu oraz jedno spotkanie celem dokonania obserwacji (uczestniczącej) w trakcie ćwiczeń. Kontakt z badanymi nawiązywany był za pośrednictwem informatorów, którymi były osoby ćwiczące w siłowniach. Wywiady prowadzone były według wcześniej ustalonych dyspozycji, które w każdym przypadku były takie same, nie ograniczały jednak przebiegu narracji. W czasie wywiadu badany naprowadzany był jedynie na opowiadanie o konkretnej fazie życia lub o konkretnym obszarze tematycznym. Strategia jakościowa umożliwiła dotarcie do głębi sensu wywiadów przy dokonywaniu analizy. Analizy danych dokonywane były dwuetapowo. Zastosowana została analiza egzemplifikacyjna i typologiczna (Paprzycka 2012, s. 57).

\section{Konstruowanie męskiej tożsamości wizualnej}

W tradycyjnych społeczeństwach męskość i kobiecość są ściśle określone. Proces socjalizacji i samowychowania zmierza do utożsamienia się jednostki z obrazem kobiety lub mężczyzny funkcjonującym w kulturze. Brak realizacji oczekiwań społecznych stwarza sytuację „odmieńca”, ocenianą przez system kontroli społecznej. Pojawia się narzucany przez normatywność konstrukt płci reprodukowany w dyskursie społecznym. Konstrukcje męskości w kulturze tradycyjnej generują libido męskiej dominacji. Tożsamość jednostki zależy od jej wyobrażenia, kim jest, dokąd zmierza oraz od zdolności do podtrzymywania ciągłości określonej narracji. Płeć ujmowana jako kategoria społeczna staje się informacją, na podstawie której tworzone są sądy. Sposoby definiowania męskości przez badanych mężczyzn, ich poczucie bycia mężczyzną zdeterminowane są przez definicje funkcjonujące w społeczeństwie. Powielanie obowiązujących wzorców następuje w momencie, w którym własne poczucie tożsamości płciowej pasuje do funkcjonującego w społeczeństwie. Badani, akcentując cechy stereotypowo przypisywane męskości, potwierdzać się zdają słowa Bourdieu (2004, s. 67), według którego, pomimo że męskość w teatrze gendered society może być inscenizowana, nie może jednak być całkowicie zmieniona lub zastąpiona. Badani zdają się powielać tradycyjne wzorce męskości. Ich poczucie męskiej tożsamości przekłada się na ich tożsamość w ogóle. Może być to odzwierciedleniem tezy Eugenii Mandal (2010, s. 204) o tożsamości płciowej jako subsystemie tożsamości. Otwartość na cielesność może być wynikiem redefinicji męskości w społeczeństwie.

Badani definiują męskość przez pryzmat cech psychicznych oraz fizycznych. W swych narracjach wskazują na wagę tradycyjnie określanych cech męskich w definiowaniu męskości. Dotyczy to przede wszystkim względów osobowościowych i charakterologicznych. Takie ujmowanie męskości może być wynikiem 
stałych wzajemnych interakcji między determinantami poznawczymi, behawioralnymi i środowiskowymi (Bandura 2007, s. 17). Pytani o definicję męskości potrzebowali dłuższej chwili na zastanowienie się. Pytanie dziwiło ich. Reagowali stwierdzeniem „facet to facet”. Może to świadczyć o bezrefleksyjnym powielaniu wzorców kulturowych i odgrywaniu ról płciowych. Podkreślali jednak znaczenie budowania swego wizerunku, swej tożsamości wizualnej. Chęć wywierania określonego wrażenia na innych jest dla nich jedną z głównych motywacji. Autoprezentacja jest podstawowym warunkiem udanych kontaktów osobistych i zawodowych.

Mandal przedstawia autoprezentację jako intencjonalny proces kierowania lub zarządzania wrażeniem wywieranym na innych w trakcie społecznych interakcji. Autorka twierdzi, że jednym z prostszych sposobów autoprezentacji jest używanie rekwizytów i dekoracji (strój, fryzura, zapach, wystrój wnętrza, wybór uprawianych ćwiczeń fizycznych, dyscyplin sportowych, opalanie się, rodzaj diety). Chęć dostosowania własnego wizerunku do oczekiwań otoczenia potęguje strach przed negatywnymi ocenami (Mandal 2010, s. 64). Andreas Schneider wyjaśnia, jak ludzie stają się kolekcjonerami tożsamości zorganizowanych w hierarchię ważności. Twierdzi, że tworzą obraz siebie na podstawie reakcji innych. Według niego budowanie siebie to proces osiągania niejasnych celów przy użyciu ograniczonych narzędziach. Wymaga on zaangażowania, bycia aktorem, refleksji nad sobą (Schneider 2007, s. 5). Zdaniem Alicji Kuczyńskiej (1983, s. 9) człowiek używa swego ciała jako podstawowego środka wyrazu. To cielesność kształtowała kanony wszystkich historycznych estetyk. Człowiek, według autorki, może pozorować sytuacje, udawać kogoś innego niż jest w istocie. Może eksponować wartości, jakich nie posiada, inne natomiast ukrywać. Dzieje się tak dzięki rzeczom, przedmiotom materialnym, zachowaniom, treściom duchowym. Cielesność jest uzupełniana przez ludzi coraz nowszymi przedmiotami, kamuflującymi jej pierwotną istotę. Monika Bakke (2000, s. 9) postrzega ciało jako miejsce przechodzenia impulsów docierających ze świata, jak i tych wychodzących z ciała, stanowiące wizualny dowód zmienności jako zasady świata, pole indywidualnej i zbiorowej inskrypcji. Elisabeth Grosz (1990, s. 25) twierdzi, że jest ono delikatne, wrażliwe i inspirujące, a naturalne dla człowieka są starość, choroba i śmierć. Magdalena Sarnińska-Górecka (2008, s. 163) posługuje się metaforą „ciała-kostiumu”, której używa w odniesieniu do płciowości. Pojęcie kostiumu zapożyczone zostało z teorii performatywności, która zakłada, że kobiecość i męskość to kostiumy zawierające elementy charakterystyczne dla danej kategorii płciowej. Obie płcie określają się przez styl bycia, sposób konstruowania swego wizerunku. Granicą dowolności są normy kulturowe i społeczne ograniczenia. Kostium „prawdziwej męskości” postrzegany jest w kulturze współczesnej w sposób tradycyjny (samiec alfa). Wielu mężczyzn zamyka się na zmiany związane z definiowaniem męskości, które postrzegane mogą być jako korzystne wyłącznie dla kobiet. Emancypacja wyzwoliła je spod władzy mężczyzn i z tego punktu widzenia mężczyzna poniósł stratę. Jednakże, jak podaje wielu autorów (por. Brannon 2002; Renzetti, Curran 2008) zyskał on między innymi prawo do okazywania emocji, do bycia pacyfistą, słabym 
w różnych sytuacjach, czułym ojcem i troskliwym partnerem. Zdaniem Lindy Brannon (2002, s. 212-239) dzisiejsze stereotypy rodzajowe mają źródło w kulturze dziewiętnastowiecznej. Męskość przez wieki prezentowana była w opozycji do kobiecości, jako jej przeciwieństwo. Potęgowanie muskulatury uznać można za kontynuację tego obrazu (męskość-siła, kobiecość-słabość).

\section{Przykładowe narracje:}

Mężczyzna musi być mężczyzną z charakteru, czyli musi być silny psychicznie, twardy, umieć zadbać o siebie i bliskich. Jeśli chodzi o wygląd, to musi być czysty i sprawny fizycznie (Janek).

Chęć dbania o siebie i innych wiązać można z umiejętnością zapewnienia bytu sobie i rodzinie, co jest znamienne $\mathrm{w}$ tradycyjnym podejściu do roli mężczyzny. Badany, akcentując znaczenie cech charakteru w byciu mężczyzną, daje wyraz swego przywiązania do tradycji męskości. Albert Bandura (2007, s. 23) tłumaczy to uczeniem się i powielaniem wzorców funkcjonujących w społeczeństwie. Badani mężczyźni zaznaczyli również istotę cielesności w byciu mężczyzną. Ważny jest wygląd zewnętrzny i to jak postrzegają ich inni. Cielesność oraz sposób ubierania się są ważne dla badanych:

Mężczyzna wyglądać musi dobrze, powinien być wysportowany. Nawet jak ma fajne włosy, ciuchy, a ciało jak flak, to co to za chłop. Chociaż jak fajnie zachowuje się, nie jak pipa, fajnie jest ubrany, zadbany, to nawet że nie ćwiczy, to jest ok. Nie lubię tych, którym się nie chce i dobudowują filozofię, jak to nie mają czasu.

Druga część wypowiedzi wskazywać może na preferencje modowych możliwości dostępnych dla mężczyzn. Umiejętny sposób dobierania odzieży zdaniem badanego kamuflować może niedostatki cielesne. Takie podejście może być wynikiem nacisku branż modowo-kosmetycznych na współczesnych mężczyzn. Wymogi stawiane mężczyznom przez media stawać się mogą niedoścignionym ideałem. Badani męskość kojarzą z fizycznością:

Jak kobieta widzi faceta, który jakoś tam wygląda, jest czysty, dobrze ubrany, pachnący, przechodzą do rzeczy, on się rozbiera, a tam obrzydliwe zwały tłuszczu, to tylko zacząć krzyczeć i uciekać. Facet wszystko musi mieć na miejscu (Sebastian).

Strach przed posiadaniem otłuszczonego ciała pojawiał się w większości narracji. Może to być związane z zaburzeniem obrazu własnej cielesności (BDD), np. bigoreksją.

Badani własny wizerunek tworzyć mogą na drodze naśladownictwa lub realizacji własnego wyobrażenia wzoru męskości. Własne braki niwelowane mogą być za pomocą gry pozorów, przez nakładanie różnorakich masek (Leary 1999, s. 27). Badani tworzą fasadę dominacji, kreując swą tożsamość wizualną. Zdaniem Ervinga Goffmana jednostka swą rolę odgrywa tylko w obecności innych. Z obserwacji wynika, że większość badanych mężczyzn stara się być w roli nawet bez świadomości bycia obserwowanymi (Goffman 1981, s. 51-65). Ich sposób 
wyrażania siebie wiąże się z codziennym wkładem pracy, wysiłkiem, systematycznością i wyrzeczeniami. Praca nad sobą, swą cielesnością jest ich sposobem na budowanie własnego „ja”. Pozwala to przekazywać określony wizerunek siebie. Na konsekwentne budowanie obrazu siebie uwagę zwraca Bartek:

Facet musi dbać o swój wizerunek, powinien być piękny, nie do przesady, ale powinien dać swemu ciału szansę, ubrać też musi się jakoś. Elementy kosmetyki muszą być spełnione. Jak nie masz zapisanego tam u góry albo w genach dobrego wyglądu, dobrych proporcji ciała, to żebyś się skichał, nic nie osiągniesz i nic z tym nie zrobisz. Starać się jednak zawsze warto.

Narracja badanego wskazywać może na jego obsesyjne dbanie o wygląd. Może to być efektem poddania się medialnej dyktaturze. W wypowiedzi badanego pojawia się wątek genetycznej niesprawiedliwości. Uważa on, że ludzie obdarzeni doskonałymi proporcjami zawsze będą bardziej atrakcyjni. Wypowiedź ta sugerować może odnoszenie się badanego do kanonów urody i wydaje się on podejmować próby sprostania ideałom. Ton jego głosu sugerować jednak może brak zadowolenia z uzyskiwanych efektów. Zwraca również uwagę na hierarchię panującą w siłowni:

Wiadomo, jak jest w siłowni, jesteś nowy, to musisz płacić frycowe, jesteś starym wyjadaczem, to masz luz i poklask.

W dalszej części narracji badany podkreśla swój wiek:

Z biegiem czasu mam jakieś tam kontuzje, wiadomo, trzeba na siebie bardziej uważać, organizm już się tak nie regeneruje. Ciało już troszkę sfatygowane, traci jędrność, tłuszczyk się odkłada, dlatego w pewnym wieku trzeba mądrze do tego podchodzić, nie na wariata jak za młodzika. Wszystko musi być dokładnie przemyślane, dieta, trening, tak aby wyglądać wciąż dobrze, a nie na dziada.

Wypowiedź ta ukazuje profesjonalne i przemyślane podejście do ćwiczeń. Badany, mając świadomość upływającego czasu, stara się dostosowywać trening do możliwości organizmu. Jego umiejętność korygowania treningów i potrzeba posiadania odpowiedniego wyglądu wiązać się może z wykonywaną pracą:

Jakbym siedział taki tłusty i obleśny, to każdy w siłowni miałby mnie za idiotę, a nie instruktora. Ta posada wymaga profesjonalizmu. Ludzie wierzą w to, co im mówi instruktor, tylko gdy widzą, że jest on idealnie zadbany. Jak miałbym przekonać kogoś do diety, ćwiczeń, zapewniać go, że dzięki temu będzie super, jeśli sam bym tego sobą nie reprezentował? To jakaś straszna farsa.

Badany w swej wypowiedzi zwraca uwagę na potrzebę spójności wizerunku cielesnego z wykonywaną profesją. Podejście badanego wpisuje się w definicje wizerunku i sposoby jego urealniania. Trenerzy PR akcentują znaczenie świadomej autokreacji.

Męskość hegemonialna realizuje się przez używanie przemocy wobec kobiet i słabszych przedstawicieli własnej płci. Jest ona wspomagana przez system 
mechanizmów ustawodawczych, prawnych, politycznych ${ }^{1}$. Reprodukcja hegemonii odbywa się przez proces wychowania. Connell $(1995$, s. 76) opowiada się za pojmowaniem męskości i kobiecości jako projektów płciowych. Zwraca uwagę na procesy i relacje skłaniające kobiety i mężczyzn do zachowań zdominowanych przez kategorie płci (doing gender). Męskość definiuje jako „pozycję w relacji płci, praktyki zajmowania tej pozycji przez mężczyzn i kobiety oraz oddziaływanie tych praktyk na doświadczenia związane z cielesnością, na poszczególne osobowości i na całą kulturę" (Connel 1995, s. 75). Stawia tezę o istnieniu wielu modeli męskości, które powstają w określonych warunkach historycznych, topograficznych, kulturowych (podlegają zmianom, ewoluują). Charakteryzując konstrukcję męskości w kulturze, dystansuje ją od koncepcji biologicznej determinacji płci. Twierdzi, że ciało jest również uczestnikiem procesów socjalnych, obiektem praktyk, które tworzą owe procesy. Każda forma męskości jest zakorzeniona w strukturach relacji podlegających historycznym modyfikacjom.

Głównym pojęciem kulturowo-socjologicznej koncepcji płci według Bourdieu (2004, s. 100) jest habitus usytuowany w momencie stykania się ciała i społeczeństwa. Habitus jest związany z indywidualnym ciałem, ale jest wyrazem przynależności do grupy społecznej. Pojęcie to używane jest do wyróżniania grup społecznych, charakteryzowania ich stylu życia oraz określania pozycji w relacji płci. Monika Szczepaniak (2010) zwraca uwagę na mechanizm konstrukcji płci w koncepcji Bourdieu, bazujący na odpowiednim zaaranżowaniu ciała w systemie praktyk społecznych, na inkorporacji relacji panowania. Zauważa, że Bourdieu eksponuje władzę symboliczną, która działa, używając zhabitualizowanych wzorców (bez kontroli woli i autorefleksji). Jednostka poddaje się więc zakazom, sugestiom itp. Bourdieu (2004, s. 110) pisze o procesie somatyzacji relacji, gdzie „androcentryzm narzuca się jako neutralny i niewymagający dyskursywnej legitymizacji”. Ciało ustawicznie reprodukuje się. Fundamentalne dyspozycje narzucają społeczne strojenie ciała. Szczepaniak (2010) akcentuje konstruowanie płci przez Bourdieu w przestrzeni przeddyskursywnej, na płaszczyźnie spontanicznego działania zdeterminowanego przez wpisane w ciało praktyki płciowe, socjalne, kulturowe, etniczne. Ciało, jako wizytówka, staje się wyrazem miejsca zajmowanego w porządku społecznym i płciowym. Zdaniem autorki w świetle obu koncepcji porządek płciowy jawi się nie jako model zakorzeniony w strukturach ciała. Edith Wölfl (2000, s. 104) sformułowała tezę, że męskość jako projekt pozostaje kategorią historyczną, zaś jako rodzaj - uposażeniem ciała. Jako praktyka socjalna jest nadzwyczaj kruche, niestabilne i pełne sprzeczności. Przed ciałem nie ma ucieczki, jest ono nieustannie definiowane i formowane. Ta wzajemna relacja aspektów socjalnych i cielesnych powoduje, że płeć to koncept dynamiczny i kompleksowy, wymykający się interpretacjom esencjalistycznym, pozytywistycznym, normatywnym, semiotycznym (Szczepaniak 2010).

Badani budują „kostium” tożsamości płciowej z mięśni. Tworzą tożsamość wizualną, która pozwala im wpisywać się w tradycyjny dyskurs męskości. Siłownia

1 Bazowanie na męskim autorytecie, akceptacja ze strony podporządkowanych. 
staje się miejscem, w którym reprodukowane są zasady heteronormatywności. W dalszej części artykułu podjęta zostanie próba przedstawienia płynności granic pomiędzy definiowaniem męskości według osób ćwiczących w siłowniach. Dokonuje się ukonstytuowanie wzorów męskości nowoczesnej. W obrębie dwóch paradygmatów męskości wyróżnić można wiele modeli męskości. Zwrot ku cielesności mężczyzny stawia go w sytuacji nakazów i zakazów z nią związanych. Cielesność staje się jednocześnie ostoją tradycyjnych wzorców i generatorem męskości sfeminizowanej. W obrębie podejścia do ciała dojść może do przełamania schematów dwupłciowości i rozwinięcia różnorodności konstrukcji płci. Może również potęgować i podkreślać różnice płciowe. Kryzys męskości definiowany jest przez pryzmat zmian związanych z nową sytuacją mężczyzny na arenie społecznej. Zmieniający się układ sił, feminizacja społeczeństwa zachwiały niegdyś stałą pozycją mężczyzn, co wywołało poczucie zagrożenia. Paradygmat nowego mężczyzny zakłada, że powyższe cechy to stereotypowe spojrzenie na mężczyznę, któremu należy się prawo do okazywania emocji, uczuć, słabości, empatii, posiadania cech niegdyś utożsamianych wyłącznie z kobietą. Mężczyzna prezentowany jest coraz częściej jako znający się na modzie, zadbany, przyjazny człowiek używający kremów do pielęgnacji i odwiedzający SPA². Różnorodność nowych modeli męskości, wspólnie funkcjonujących w przestrzeni społecznej, ze stereotypowymi poglądami, prowadzić może do problemów z samookreśleniem. Dla wielu męskość utożsamiana jest z potencją seksualną, atrakcyjną budową płciową, dominacją. Kryzys tradycyjnych pojęć, wzorców męskości i kobiecości przyczynił się do zaistnienia trudnej sytuacji w samookreśleniu się we własnej roli.

\section{Ciało jako miejsce wpisywania znaczeń}

Cielesność oraz myślenie o niej przeszło wiele metamorfoz we wszystkich kulturach i społecznościach świata. Skutkowało to zmianami w obrębie znaczeń nadawanych ludzkiej cielesności, a tym samym zachwianiem $w$ jednoznacznym poczuciu tożsamość płciowej. To właśnie ciało człowieka stanowi jeden z naczelnych elementów podmiotowości. Jest nośnikiem biologicznych i kulturowych różnic płciowych. W jego obszarze tworzy się tożsamość. W tym procesie jednostka nie ma wpływu na cielesne techniki społeczne. Dyskurs społeczny wyznacza obszar możliwości użycia ciała. Centralnym punktem określania własnej tożsamości zdaniem Sarnińskiej-Góreckiej (2008, s. 164) staje się indywidualność z cielesnością, która jest jednostce dana i którą sama kreuje. Poprzez cielesność może tworzyć siebie, kreować swój wizerunek, wpływać na sposób odbierania jej przez innych, odnajdować lub nie swą tożsamość płciową, płeć społeczną, która jest zdaniem Judith Butler (2006, s. 123) nośnikiem obowiązkowej, determinującej, wymuszonej praktyki ucieleśniania norm. Instynkty i odruchy zostają stłumione

2 SPA (sanitas per aquam - zdrowie dzięki wodzie) - ośrodki wypoczynkowe mające w swej ofercie relaksacyjno-pielęgnacyjne zabiegi wodne. 
na rzecz ucywilizowania ciała, poprawiania go i udoskonalania zgodnie z aktualnymi normami, a atrybuty danej płci stają się płynne między obiema płciami. Dominika Dzido (2006, s. 172) zauważa, że własne ciało może okazać się wcześniej nierozpoznanym. Stało się ono tematem refleksji w dyskursach wielu nauk. Przywołuje ona termin somaties wyrażający współczesne zainteresowanie kwestią cielesnej tożsamości. Pytanie o istotę cielesności nasuwa wiele odpowiedzi. Pojawiła się kategoria ciała zdyscyplinowanego, poddanego aktualnym wymogom i wzorcom piękna. Nasycanie ciała określonymi treściami powoduje, że staje się ono wytworem społecznym. Problematykę ciała jako wytworu kultury podejmują studia feministyczne oraz maskulinistyczne (men's studies). Wyszczególnia się obecnie ciała dyskursywne i materialne, fizyczne i komunikacyjne, konsumpcyjne i medyczne, indywidualne i społeczne. Wspomniana wyżej autorka w swoich rozważaniach o cielesności podejmuje wątek ciała mającego płeć, wypełnionego kulturowymi treściami. Formułuje ona termin „ciała upłciowionego”, który obejmuje problemy i zagadnienia związane ze znaczeniem płci w ciele. Kulturowa tożsamość płci określana jest jako "gender”, a więc teoretyczna konstrukcja wprowadzona przez feminizm. Norma kulturowa, zdaniem Butler (2006, s. 220), realizowana jest na powierzchni ciała. Balejko (2001, s. 136) nazywa to „ucieleśnieniem normy”. Inne zachowania, pozy, sposoby konstruowania wizerunków są charakterystyczne dla kobiet, a inne dla mężczyzn. Człowiek jest poddany znaczeniom związanym z płcią. Perspektywa gender daje możliwość oglądu rzeczywistości społecznej pod względem kulturowej tożsamości płci usytuowanej w ciele. W ciało, według Bourdieu (2000, s. 35), wpisane są schematy działania charakterystyczne dla określonych grup społecznych. Sposoby używania ciała mówią o przynależności do danej klasy. Na poziomie ciała przejawiać się może różnorodność upodobań - uprawiany sport, ubiór, pielęgnacja to wyrazy przynależności do określonego kontekstu społecznego. Ciało wyposażone w znaki również wytwarza znaki. Przynależność lub utożsamianie się z daną grupą określa stosunek do ciała. Gustowanie zdaniem Bourdieu (2000, s. 120) przejawia się w codziennych praktykach, jak jedzenie, ubieranie, poruszanie się. Ciało stanowi odbicie gustu. Język ciała, ubiór, poziom zadbania czy wysportowania informują o społecznej przestrzeni życia. Autor zauważa różnice w podejściu do własnego ciała między mężczyznami a kobietami. Słowa habitus użył, mając na myśli codzienne uzewnętrznianie „praktyk cielesnych”. Kaufmann (2003, s. 65) pisze, że przyzwyczajenie nie znajduje się $\mathrm{w}$ ciele, lecz $\mathrm{w}$ ciele poszerzonym, wpisanym $\mathrm{w}$ uniwersum społeczne. Zygmunt Bauman (2004, s. 163) twierdzi, że ciało staje się polem praktyk o szczególnym znaczeniu dla tożsamości jednostki. Uatrakcyjnianie ciała ma na celu ukształtowanie określonego wizerunku. Według Krajewskiego (1997, s. 67) tożsamość zostaje zrównana z pewnym wizualnym sygnałem-poszlaką, którą inni mogą zobaczyć i której znaczenie można rozpoznać zgodnie z sygnałem nadawcy. Te sygnały mogą dotyczyć kształtu ciała, ozdób, domu, bywania w określonych miejscach. Uczęszczanie do klubów fitness można utożsamiać z refleksyjnym projektowaniem swojej tożsamości, wyglądu i wizerunku. Zdaniem Philipa Zimbardo (1988, s. 547) ludzie podejmują ogromny wysiłek, by osiągnąć korzyści w postaci 
bycia dostrzeżonym przez innych, szacunku, miłości, podziwu. Jego zdaniem wiąże się to z potrzebą bycia społecznie aprobowanym, dzięki czemu zyskać można poczucie tożsamości.

\section{Przykładowe narracje:}

Marcin w swej narracji wskazuje na trzy etapy podejścia do (mniej lub bardziej) muskularnego ciała:

1) muskulatura jako atrybut sportowca,

2) muskulatura jako atrybut bandyty,

3) muskulatura jako atrybut mężczyzny modnego.

Badany mówi również o potrzebie eksponowania swoich umiejętności:

Kiedyś byłem na wakacjach i poszedłem do siłowni, miałem zrobić lekki trening, ale przyszli jacyś faceci, troszkę umięśnieni, ale mi nie dorastali. Strasznie cwaniakowali, więc pomyślałem, że muszę pokazać im, gdzie jest ich miejsce i zrobiłem taki trening, że im oczy zbladły. Wiem, że jest w tym coś z instynktu zwierzęcego. Musiałem jak paw zaprezentować uroki swego ogona.

Kolejna część wypowiedzi ujawnia próby maskowania swoich kompleksów muskulaturą:

Ja zawsze chciałem być przypakowany na maksa. Nie jestem wysokim przystojnym brunetem, więc pomyślałem, że superlaski polecą na mięśnie. Nie było tak jednak. Laski teraz to patrzą na pozycję faceta. Strasznie się zrobily opłacalskie.

Z wypowiedzi wnioskować można, że jednym z głównych powodów rozpoczęcia pracy nad swoją cielesnością był popęd seksualny. Chęć zdobywania kobiet stała się motywacją dla badanego, który wydaje się być rozczarowany brakiem spodziewanych efektów. Mateusz zdaje się być zadowolony ze stereotypowego podejścia do umięśnionych mężczyzn:

Trzeba przyznać, że wysportowana sylwetka, mięśnie odznaczające się pod koszulą, robią wrażenie na ludziach. Nie wiedzą, co myśleć. Często kojarzy im się to jeszcze $\mathrm{z}$ bandytami, więc wolą się usunąć.

Z narracji badanego wynikać może, że powodem, dla którego ćwiczy, jest budzenie postrachu. Bazuje on na stereotypowym podejściu do mężczyzn muskularnych. Zła sława „mięśniaków” zdaje się być dla niego atutem. Może to być wynikiem nacisku otoczenia, w którym funkcjonuje. Społeczne uczenie się ma wpływ na wybieranie i odtwarzanie określonych zachowań (Bandura 2007, s. 35). Muskularność i wysoki wzrost utrudniają kontakty interpersonalne Sebastianowi:

Mój wygląd to był zawsze problem. Ja stwarzam problem, jak jadę do ludzi coś załatwiać, to jest od razu mur, przez który muszę się przebić. Ludzie mój wygląd uznają za gruboskórność, za chamstwo, jak stanowczym głosem mówię, to proszą, żebym nie krzyczał. Jak jest się zadbanym i eleganckim, to wtedy myślą, że jesteś bogaty i wtedy są utrudnione relacje. 
Badany ubolewa nad ocenianiem człowieka przez pryzmat powierzchowności. Jego zdaniem ludzie oceniają nowo poznaną osobę stereotypowo. Męskość z muskulaturą utożsamia Dominik:

Uważam, że muskulatura dodaje mężczyźnie męskości, no tak się wydaje ludziom. Można jednak się zdziwić, wiem, że geje też dbają o siebie i też mają muskulaturę i tak dalej, ale tego nie widać na zewnątrz, więc każdy myśli i o geju, że to jest ten stuprocentowy mężczyzna. No trudno, wolałbym, aby tak nie było.

Wypowiedź pełna jest negatywnych opinii na temat osób o odmiennej orientacji seksualnej. Badany chce, aby muskulatura była utożsamiana wyłącznie z mężczyznami heteroseksualnymi. Świadczyć to może o homofobii badanego. W dalszej części wypowiedzi ujawnia swe oczekiwania związane z posiadaniem muskulatury:

Jak człowiek przejdzie się latem po plaży, odtłuszczony, umięśniony, opalony, natarty olejkiem, to kobiety się za nim oglądają, a faceci ciężko przełykają ślinę, boją się spojrzeć, że mogą dostać w ucho i boją się o swoje kobiety, że je stracą naturalnie.

Wypowiedź ta obrazuje stosunek badanego do muskulatury. Daje mu ona poczucie przewagi nad innymi mężczyznami. Staje się ona płaszczem ochronnym, dającym siłę i pewność siebie. O próbach sprostania swym oczekiwaniom mówi Krzysztof:

Nie interesuje mnie to żeby się wbić w coś, ale być zadowolonym z siebie, nie mieć kompleksów, a to osiągnę wtedy, gdy uznam, że osiągnąłem, a stereotypowy wygląd będzie jakimś dodatkiem, o tym nie myślę w ogóle. To już samo przyjdzie, że ktoś powie, że jestem stuprocentowym mężczyzną. Nie zależy mi na tym specjalnie, chcę przede wszystkim być zadowolonym sam z siebie, na tym mi zależy.

Badany ma potrzebę bycia postrzeganym jako prawdziwy mężczyzna. Służyć ma temu podejmowana aktywność fizyczna. W dalszej części narracji mówi o wyższości nad innymi mężczyznami, jaką daje wygląd:

Jak jesteś wielki, to inni faceci patrzą na ciebie i czują respekt. Wolą nie podchodzić. Muszą znać swoje miejsce mięczaki. Od jakiegoś czasu czuję się w siłowni bardzo dobrze, zwłaszcza po kilku miesiącach diety zaczynam się czuć coraz lepiej, bo moja sylwetka się zmienia. Gdy wyglądałem gorzej, to i na siłowni czułem się gorzej. Im gorzej człowiek wygląda tym czuje się gorzej. Jak chodzę o 6 rano, by po pracy mieć czas dla dziecka i jest nas tylko trzech, to nie ma hierarchii, ale jak chodzę o innych porach, to jest. Kolesie bardziej przypakowani trzymają się razem, a z leszczami nikt nie rozmawia.

Wiąże samopoczucie z wyglądem. Zadowolenie z cielesności przenosi na zadowolenie z życia. O zaufaniu, które budzą wysportowani mężczyźni, mówi Aleksander:

Mężczyzna elegancki, zadbany, wysportowany budzi większe zaufanie. 
Wypowiedź traktować można jako obalającą stereotyp łączący masę mięśniową z siłą.

Dobrze wyglądam i to wiem. Większość kobiet patrzy na mnie i widzę, że im się podobam. Widzę ich to, ich mowa ciała mówi wszystko. W pracy, jak jest trudna klientka, to szefostwo mnie wysyła, bo twierdzą, że żadna kobieta mi się nie oprze. Ja nie czuję potrzeby walki, czuję się lepszy od niektórych mężczyzn, no modelem też nie jestem, ale jest ok.

\section{O zaletach ćwiczeń mówi Borys:}

Jeszcze kilka lat temu, jak zaczynałem ćwiczyć, znajomi dziwili się, że prawnik i chodzi do miejsc kojarzonych z przestępcami. Nie rozumieli, że tam się ćwiczy i już. Teraz sami chodzą, bo to zaczęło być modne i wręcz konieczne, bo wiele spraw można ustalić, omówić, właśnie w kuluarach, w jacuzzi, na rowerku, w saunie itp. No, nie jest łatwo na początku, mi było trochę trudno, człowiek boi się, że go wyśmieją, przepędzą, ale się zawziąłem i teraz jestem tam jak u siebie.

Badany dostrzega związek między wyglądem a wykonywaną profesją:

Mój zawód wymaga ode mnie abym był elegancki i zadbany, to ułatwia relacje z innymi ludźmi. Hm? Choć nie zawsze. Zależy z jaką grupą społeczną przychodzi mi rozmawiać, jeżeli są to ludzie z takiej, powiedzmy, klasy niższej, mniej wykształceni, wtedy jednak postrzegają ciebie jako człowieka takiego jakiegoś lepszego od siebie. Czuję jak inni faceci w moim wieku patrzą na mnie z zazdrością. Czuję się wtedy lepszy od nich, wiem, że dobrze wyglądam, czuję się świetnie, a oni to jakieś zgrzybiałe dziadki.

Badany, ćwicząc, zyskał zadowolenie ze swego wyglądu, a tym samym poczucie pewności siebie i przewagi nad rówieśnikami.

Odpowiedzią na androgyniczny wzór męskości i feminizację dla wielu mężczyzn stała się hipermęskość. Hipermężczyzna jest samcem alfa w tradycyjnym ujęciu. Przedrostek hiper potęguje wszystkie cechy. Jest silny i muskularny. Przekracza granice muskularności, wynosi ciało na szczyt piękna i tężyzny fizycznej, co często osiąga za pomocą chemicznych środków wspomagających. Czyni to za cenę sprawności seksualnej, rozbicia wewnętrznego, stanów euforyczno-depresyjnych wywołanych przyjmowaniem środków anabolicznych.

Bauman (2006, s. 131) tożsamością nazywa dzieło sztuki formowane z kruchej materii życia. Utożsamia ją z harmonią, logiką, spójnością, których brak człowiekowi „w strumieniu doznań”, a jej poszukiwanie z „nieustanną próbą zatrzymania lub choćby spowolnienia biegu strumienia”. To, co nazywane jest tożsamością autor nazywa „wierzchnią warstwą wulkanicznej lawy, która twardnieje raz po raz w różnych miejscach, lecz nim zdąży na dobre ostygnąć i skrzepnąć, ponownie topi się i rozpuszcza, a żywa, autentycznie doświadczana tożsamość może nabrać spójności jedynie dzięki pracy wyobraźni albo po prostu dzięki marzycielstwu" (Bauman 2006, s. 131-249). Jest to powód popularności tożsamości tymczasowych, dających możliwość szybkiej zmiany. Życie człowieka stało się niepewne, pozbawione stałego gruntu. W obliczu braku długotrwałego poczucia bezpieczeństwa 
zdaniem Baumana natychmiastowa satysfakcja jest ukojeniem, a świat staje się „pojemnikiem pełnym przedmiotów jednorazowego użytku (2006, s. 249). Tworzenie tymczasowych definicji siebie pozwala na uniknięcie poczucia rozczarowania. Tomasz Leszniewski (2001, s. 55) zwraca uwagę na poczucie nudy. Nawiązuje to do wcześniej opisanego Baumanowskiego wzoru człowieka ponowoczesnego. Zmieniający się układ sił w społeczeństwie wywołuje poczucie zagrożenia u wielu mężczyzn. Obawiając się zmiany porządku, w którym zostali wychowani, kryzysów wewnętrznych, które mogą ich dotknąć, szukają ratunku w postawach antagonistycznych do androgynii. Granice między męskością a jej brakiem stały się płynne. Mężczyźni gubią się w natłoku informacji, co jest jednym z powodów kryzysu męskości. Ciało staje się łącznikiem męskości tradycyjnej, hegemonicznej $\mathrm{z}$ nowoczesnością. Elementy zatopione w tradycji dają badanym poczucie stabilnej tożsamości.

\section{Podsumowanie}

Zdaniem Melosika (2006, s. 156) ponowoczesne podejście do płci stanowi punkt wyjścia interpretacji społecznych kontekstów ciała. Staje się ono tekstem, w który wpisywane są społeczne znaczenia męskości/kobiecości. Może być czytane. Badani chcą być odczytywani jako silni i sprawni dominatorzy. Ich zdaniem muskulatura jest wizytówką siły, dającą im przewagę nad resztą mężczyzn. Ciało stało się tworem zindustrializowanym. Sformułowania "ciało zindustrializowane” (the industrialized body) użył Lionel Tiger (2000, s. 29) na określenie uprzemysłowienia społeczeństw na poziomie ciał obywateli. Autor (będący jednym z głównych propagatorów koncepcji male studies) uważa, że współczesna ludzkość ignoruje lub całkowicie odrzuca swoje korzenie, naturę i fakt bycia Homo sapiens. Pisze on o ignorancji prehistorii, która żyje w genach i ciele człowieka, mającego stare portfolio potrzeb i odruchów. Brak wsłuchiwania się w siebie, ślepe podążanie za aktualną modą, to skutki industrializmu, żądającego absolutnego zaangażowania w bycie częścią wielkiej maszyny.

Potrzeba budzenia respektu i strachu może mieć swoje źródło w kompleksach z okresu dzieciństwa. W narracjach badanych pojawił się również aspekt dominacji związanej z bywaniem i posiadaniem określonej specjalistycznej wiedzy. Jeden $z$ badanych nie czuje potrzeby walki z innymi, czując się od nich lepszym. Dwóch badanych twierdzi, że zachowania agresywne i praca ochroniarza w dyskotece były powodem kłopotów w ich życiu. Pojawiły się wypowiedzi obalające stereotyp łączący muskulaturę z siłą. Trzech badanych twierdzi, że posiadanie dużych mięśni nie jest wystarczające, konieczna jest również biegłość w sztuce walki. Potwierdza to zdanie Lopeza, Hodsona i Roscigno (2009, s. 26), którzy uważają, że mężczyźni pragną władzy nie tylko nad kobietami, ale i nad innymi mężczyznami. Chęć jej utrzymania i dominacji może prowadzić zdaniem Sallaza (2002, s. 98) do dręczenia (harass) innych mężczyzn (np. w miejscu pracy, w siłowni itp.). Autor twierdzi, że dominacja nad innymi mężczyznami odbywa się za pomocą 
sprowadzania ich do pozycji kobiet (feminizing) lub przez przymusowe narzucanie dominujących płciowych norm. Owa sytuacja jest przenoszona jednocześnie na ogół społecznych stosunków męsko-męskich. Postrzeganie siebie jako umięśnionego, groźnego mężczyzny daje badanym poczucie pewności siebie oraz władzy nad innymi. Cielesność jest dla nich jednym z podstawowych środków wyrazu. Dzięki niej możliwe jest eksponowanie nieposiadanych wartości, a ukrywanie wad (Kuczyńska 1983, s. 9). Badani dekorują swą cielesność muskulaturą. Potwierdza to tezę Kuczyńskiej o kamuflowaniu pierwotnej istoty ciała. $Z$ obserwacji badanych $w$ trakcie ćwiczeń wynika, że z powagą podchodzą do treningów. W siłowni są znani, podziwiani, czują się jak u siebie. Budują w ten sposób pewność siebie, odczuwają satysfakcję. Większość badanych w siłowni jest ekspertami. Mają dużą wiedzę, długi staż w trenowaniu. Posiadają odpowiednią sylwetkę i wypracowaną przez lata opinię. Daje im to poczucie władzy i kontroli nad innymi. Badani nie zwracają uwagi na współćwiczące osoby początkujące, które patrzą na nich z podziwem. Rozmawiają jedynie z podobnymi sobie kolegami. Potwierdza to hierarchię panującą $w$ siłowni. Jest ona specyficznym miejscem, w którym ludzie, ćwicząc obok siebie, tworzą mniej lub bardziej zintegrowaną grupę pracującą nad inscenizacją (Goffman 1981, s. 115-127). Każdy jej członek ma swoją rolę, której złe odgrywanie może popsuć cały występ, a stosunki społeczne powstają przez wymianę dramaturgicznie uwznioślonych działań, reakcji na działania. Wszyscy podlegają socjalizacji polegającej na uczeniu się posługiwania "chwytami”. Z przeprowadzonych obserwacji wynika, że badani, by zaznaczyć swoją pozycję w siłowni, stosują następujące chwyty: głośne rozmowy, śmiech i wykonywanie ćwiczeń, chodzenie po całej siłowni i rozciąganie się, ostentacyjne dobieranie ciężarów, zmianę treningu, by zaprezentować swoją siłę wspótćwiczącym, napinanie mięśni przed lustrem (tzw. przypinka), zakładanie odpowiednich ciuchów: są to duże t-shirty o poszerzającym kroju, koszulki bez rękawów podkreślające mięśnie ramion, pasy na talię, rękawiczki, spodnie (tzw. pumpki).

Badani mężczyźni w siłowni czują się pewnie. Dzięki swej wiedzy, muskulaturze i długoletnim treningom znajdują się na czele hierarchii. Ćwiczą z pełnym zaangażowaniem, nie pozwalając sobie na długie przerwy i rozmowy. Na treningach, pomimo dużej koncentracji, pamiętają o otaczających ich osobach i o konieczności ciągłego budowania swego wizerunku. Wyprostowane sylwetki wskazują na dużą pewność siebie. Istotne jest dla nich to, jak wyglądają i jakie wrażenie robią na innych. Twierdzą, że ich wysportowane, umięśnione sylwetki pozwalają im być odbieranymi jako prawdziwi mężczyźni. Wszyscy ćwiczący są opaleni i pachną markowymi perfumami. Świadczy to o dbałości o ciało również od strony estetyczno-kosmetycznej. Stosowanie zabiegów pielęgnacyjnych (m.in. kosmetyki, solarium) może być odzwierciedleniem nowego podejścia do męskości. Badani zwrócili uwagę na zdrowotny aspekt ćwiczeń. Ci, którzy przekroczyli 40 rok życia, uważają, że wysportowana sylwetka pozwoli im dłużej zachować sprawność, dobry wygląd, a tym samym młodość. Obawiając się starości, inwestują $\mathrm{w}$ ciało. 
Głównym pojęciem kulturowo-socjologicznej koncepcji płci według Bourdieu (2004, s. 100) jest habitus usytuowany w momencie stykania się ciała i społeczeństwa. Habitus jest związany z indywidualnym ciałem, jest wyrazem przynależności do grupy społecznej. Pojęcie to używane jest do wyróżniania grup społecznych, charakteryzowania ich stylu życia oraz określania pozycji w relacji płci. Kariera, posiadanie dóbr materialnych i władzy są według badanych nieodłącznym atrybutem męskości. Mężczyzna niespełniony finansowo (lub niebędący na drodze do potęgowania swych dóbr materialnych), jak uważają, nie jest w pełni mężczyzną. Czują mobilizację w dążeniu do bogactwa, co zdaniem Goffmana (1981, s. 38) jest motywowane chęcią wywarcia wrażenia prowadzącego do osiągnięcia założonego celu. Może nim być próba przejęcia kontroli nad innymi. Foucault (1995, s. 84) pisze o rozproszonej władzy, działającej jak mgiełka w aerozolu, rządząca człowiekiem. Skłania ona do przynależności do określonych klubów, posiadania wybranych produktów, generuje potrzebę bycia, co tworzy specyficzną, goffmanowską fasadę z dekoracji. Kilku badanych mężczyzn nie chce rozmawiać na temat finansów, twierdząc, że trzeba je pomnażać, a nie o nich mówić. Podzielają oni jednak zdanie pozostałych, że prawdziwy mężczyzna musi być bogaty. Ich niechętne opowiadanie o majątku dowodzić może wierności tradycyjnym ideałom, według których elegancki mężczyzna nie rozmawia o pieniądzach. Może jednak być próbą ucieczki przed niewygodną tematyką. Marody i Giza-Poleszczuk (2000, s. 70) jako moment renegocjonowania tożsamości płciowej w Polsce (po 1989 roku) wskazują „powrót mężczyzny przez duże M”. Obraz męskości artykułowany był jako osoby fizycznie sprawnej i atrakcyjnej, silnej, władczej, indywidualnej, dobrze zarabiającej, odpowiednio ubranej, pewnej siebie i niezależnej. Badani mówią o potrzebie posiadania prestiżu, co Bourdieu (2004, s. 78) nazwał patriarchalną dywidendą. Jego zdaniem mężczyźni, poprzez prestiż i władzę, czerpią profity z patriarchatu, nawet jeśli znajdują się na najniższych szczeblach hierarchii. Reprodukcja owych zachowań odbywa się przez proces wychowania. Autor pisze o męskim libido dominacji, a porządek płciowy traktuje jako model zakorzeniony w strukturach ciała. Prezentowanie swojego dominującego „ja” przez badanych odbywa się w sposób świadomy i przemyślany. Wkład pracy w osiągnięcie wizualnej męskiej tożsamości może być świadectwem poddania się wpływom współczesnych medialnych nacisków lub próby odgrywania roli prawdziwego mężczyzny. Goffman (1981, s. 41-43) pisze o mniej lub bardziej celowym i świadomym odgrywaniu swej roli. Wiąże się to z poczuciem przymusu ze strony środowiska (np. w określonej grupie). Jak pisze Leary (1999, s. 54), demonstrując daną postawę, jednostka przekazuje określony wizerunek siebie samej. Kontrola nad odgrywaną rolą tworzy scenę $\mathrm{w}$ grze informacyjnej. Badani, prezentując siebie w zdecydowany, wyrazisty sposób, podlegać mogą stereotypowej ocenie. Autoprezentacja badanych mężczyzn odbywa się w sposób świadomy. Jest procesem kontrolowania przez jednostkę sposobu, w jaki postrzegana jest przez innych. Stanowi to podstawowy i nieunikniony aspekt życia społecznego. Demonstrując dane postawy, jednostka przekazuje określony wizerunek siebie. Wywieranie 
pożądanego wrażenia na innych ma poważne implikacje. Może zwiększyć liczbę nagród oraz zmniejszyć koszty (Leary 1999, s. 27).

\section{Literatura:}

Bakke M., 2000, Ciało otwarte filozoficzne reinterpretacje kulturowych wizji cielesności, Poznań.

Balejko D., 2001, Teatr ról ptciowych. Teorie o performatywnym charakterze tożsamości ptciowej oparte na filmie Jennie Livingston Paris Is Buming oraz tekstach teoretycznych Judith Butler [w:] Gender w humanistyce, (red.) Radkiewicz M., Kraków.

Bandura A., 2007, Teoria społecznego uczenia się, Warszawa.

Bauman Z., 2006, Ptynna nowoczesność, Kraków.

Bauman Z., 2004, Dwa szkice o moralności ponowoczesnej, Warszawa.

Benjamin L.T., Hopkins J.R., Nation R.J., 1987, Psychology, New York.

Bourdieu P., 2004, Męska dominacja, Warszawa.

Bourdieu P., 2001, Wacquant L.J.D., Zaproszenie do socjologii refleksyjnej, tłum. A. Sawicz, Warszawa.

Brannon L., 2002, Psychologia rodzaju. Kobiety, mężczyźni podobni czy różni, Gdańsk.

Butler J., 2006, Gender Trouble: Feminism and the Subversion of Identify, Routledge.

Campbel B., Pope H.G., Filiault S., 2005, Body Image Amonie Ariaal Men from Northern Kenia [w:] "Journal of Cross-Cultural Psychology" No. 3.

Connell R., 1995, Masculinities, Cambridge.

Dzido D., 2006, Kulturowe kody ptci [w:] Praktyki cielesne, J.M. Kurczewski (red.), Trio, Warszawa.

Etcoff N., 2002, Przetrwają najpiękniejsi. Wszystko co nauka mówi o ludzkim pięknie, tłum. D. Cieśla, Warszawa.

Flyvbjerg B., 2005, Pięć mitów o badaniach typu studium przypadku, „Studia socjologiczne”, nr 2, Wrocław.

Foucault M., 1995, Historia seksualności, Warszawa.

Goffman E., 1981, Człowiek w teatrze życia codziennego, tłum. H. i P. Śpiewakowie, Warszawa.

Grosz E., 1990, Jacques Lacan: A Feminist Introduction, Routledge.

Kaufmann J.C., 2003, Ego. Socjologia jednostki. Inna wizja człowieka i konstrukcji podmiotu, tłum. K. Wakar, Warszawa.

Kuczyńska A., 1983, Wzory modne w życiu codziennym, Warszawa.

Leary M., 1999, Wywieranie wrażenia na innych. O sztuce autoprezentacji, Gdańsk.

Leszniewski T., 2001, Moda i tożsamość - dylematy wspótczesnego człowieka w świecie konsumpcji [w:] Rozkoszna zaraza. O rządach mody i kulturze konsumpcji, T. Szlendak (red.), Wrocław.

Mandal E., 2004, Pojmowanie fenomenu ptciowości w psychologii [w:] Zrozumieć pteć. Studia interdyscyplinarne II, A. Kuczyńska, E.K. Dzikowska (red.), Wrocław.

Marody M., Giza-Poleszczuk, 2000, Być kobieta, być mężczyzna - czyli o przemianach tożsamości związanej z ptcią we wspótczesnej Polsce [w:] Między rynkiem a etatem. Społeczne negocjowanie polskiej rzeczywistości, M. Marody (red.), Warszawa.

Melosik Z., 1996, Tożsamość, ciało, władza, Toruń.

Melosik Z., 1999, Tożsamość, płeć i różnica w perspektywie ponowoczesnej [w:] Męskość-Kobiecość w perspektywie indywidualnej i kulturowej, J. Mikulska, P. Boski (red.), Warszawa.

Melosik Z., 2006, Kryzys męskości w kulturze wspótczesnej, Kraków. 
Paprzycka E., 2008, Kobiety żyjace w pojedynkę. Między wyborem a przymusem, Warszawa.

Sanińska-Górecka M., 2008, Ciało jako kostium [w:] „Colloquia Communia” nr 1-2 Kobiecość?, E. Hyży (red.), Torun.

Schneider A., 2007, The New Men: Masculinity after Traditionalism and Feminist Reaction, Lubbock.

Szczepaniak M., 2010, Libido dominacji. Męski habitus w świetle koncepcji socjologicznych, nowakrytyka.pl.

Tiger L., 2000, The Decline of Males: The first Look AT an unexpected New World for Men and Women, New York.

Wölfl E., 2000, Jenseits von Kain und Abel. Wege aus gewaltsamer Männlichkeit, München.

Zimbardo G.P., Ruch L.F., 1988, Psychologia i życie, tłum. J. Radzicki, Warszawa.

Netoteka

Mandal E., 2007, Autoprezentacja, kadry.nf.pl.

\section{Summary}

Gym as a place of constructing masculine corporeal identity

This article explores the role that gym plays in the formation and negotiation of masculinities for men: how bodybuilding serves as a masculinizing practice. It maps the set of practices, manifestations and implications for masculine corporeal identity.

\section{Keywords}

masculinity, physical strength, body, bodybuilding, identity

\section{Słowa kluczowe}

męskość, siła fizyczna, ciało, ćwiczenia, tożsamość 
